\title{
Library3.0 for Public Library
}

\author{
Hubert C. Y. Chan \\ The Hong Kong Polytechnic University, Hong Kong, China \\ Email: hubertchan@hkc.net
}

Received 24 September 2015; accepted 24 October 2015; published 27 October 2015

Copyright (C) 2015 by author and Scientific Research Publishing Inc.

This work is licensed under the Creative Commons Attribution International License (CC BY).

http://creativecommons.org/licenses/by/4.0/

(c) (1) Open Access

\begin{abstract}
The number of visitors to public library has been dropping in most of the developed cities as a result of digitalization and Internet proliferation. The role of public library has to be converted into a place for discourse, peer collaboration, social learning, and particularly inspiration through and learning from people. Social capital can thus be built up and that the process of building social capital can be part of a community development. Base on the principles of Library3.0 and Connectivism which is considered as the learning theory of this digital age, and the study of "Next" public library, this paper supports that Library3.0 implementation can facilitate this conversion with emphasis on the importance of Personalization in the creation of different space/zones for individual. Library3.0 in reality is introduced at the end.
\end{abstract}

\section{Keywords}

Web3.0, Library3.0, Learning Theory, Connectivism, Public Library

\section{Introduction}

The "classic" role of library consists in procuring, keeping up with, making accessible, relaying and archiving academic literature. It is considered as an institution of information supply with a specific information structure that operates as an intermediary between supply and demand on diverse (information) markets (Hanekop and Wittke, 2006) [1]. In the digital age, information can be disseminated through a variety of medias besides hardcopy books or journals. Library infrastructures have been modified to cope with these changes along all these years. Such modifications have increased the library expenses (Kumar and Grover, 2007) [2]. In order to accommodate the needs of users, libraries are required to increase their labor force to attend to acquisitions, promote and manage the e-journals. They must also be tech-competent to handle such responsibilities. The cost of maintaining the e-journal collection is much greater than the costs saved from printing (Montgomery and Beilec, 2000) [3]. As a result, the traditional role of library, librarian, and cost allocation have been changing in this digital age. Besides digitization, the infrastructure investment must be prioritized to achieve an economic effectiveness. 
E-lending platforms such as Amazon, Apple and more have offered packages to allow readers to borrow an e-book monthly on their Kindles for free (The Economist, Folding Shelves, 2013) [4]. With such platforms, libraries experience significant competition. Furthermore, modern day technology offers libraries with threats and opportunities. It first began when Web2.0 was released, introducing the library2.0. The characteristics of Web2.0 are rich user experience, user participation, dynamic content, metadata, scalability, openness, freedom and collective intelligence by way of user participation (Best, 2006) [5] while Library2.0 is defined as a subset of library services designed to meet user needs precipitated by the direct and peripheral effects of Web2.0 (Habib, 2006) [6]. The integration of libraries and social media sites provided a platform for discussion and enhanced the online presence of libraries. Users are able to receive updates, ask questions and share content with others conveniently through social media. With that, library is able to connect users through a variety of medias such as Skype, instant messaging, texting, social media and more for discussions. This allows library services to be more accessible as websites operate 24/7. At the same time, interaction between users and the library should be improved because they are able to provide feedback, participate and take part in the community (Vacek, 2007) [7]. Web2.0 was further developed into Web3.0. It combines the semantic web, Web2.0 applications and artificial intelligence, creates the opportunities and possibilities for the use of semantic tagging and annotation for the social web. Librarians have been using Web2.0 for organizational purposes and providing services to users. It has been serving the academic electronic library focused on the SOA (Service-Oriented Architecture), from users' perspectives (Yang et al., 2009) [8] while the application of Web 3.0 characteristics into the core functionalities of library information systems is emerging. The deployment of intelligent agents to form the semantic social web can interpret linguistic expressions of e-library users without ambiguity. In addition, the development of the real world web has enabled mobile phone connection to information service providers. Recently, Bath University in the United Kingdom incorporated QR codes into their library catalogue so that users could save book related information, such as author, title and location onto their smartphones. Users are even able to monitor library traffic through their mobile devices and find out what facilities are available at a specific time. All these allow the evolution of library2.0 to library3.0 which refers to the use of emerging technologies such as the semantic web, cloud computing, mobile devices and established tools like federated search systems, to facilitate the development, organization and sharing of user-generated content through seamless collaboration between users, experts and librarians (Belling et al., 2011) [9]. Apparently, the expansion of the digital world discourages library visits. In recent years, it has been seen that the number of visits to public library has been following a decreasing trend around the world. For instance, the visits made in person to public libraries in Ontario, Canada have dropped by about $7.5 \%$ over the course of four years. The number of active cardholders is also decreasing. Over the four years, it has decreased by about $4.4 \%$ as shown in Table 1.

Same phenomena are happening in the UK, the annual number of visitors to the library has decreased by 40 million in four years (Morris, 2015) [11]. Not only have visitors to libraries decreased, visitors to library websites have also decreased. Visits to library websites decrease at a rate of 14.4\% annually (Murdoch, 2012) [12]. This is the result of digitalization which saves the users a visit to library in person but creates a dilemma. As library has to be functioned as a place for discourse, peer collaboration, social learning, and particularly inspiration through and learning from people is more important than ever before in this knowledge base society (Bilandzic and Foth, 2013) [13]. Can the implementation of Library3.0 achieve this objective?

\section{Learning Theories and Social Capital}

To answer this research question, a review of Learning Theories is necessary. Learning theory is defined as a framework that helps us think about how and why change occurs (Smith, 2003) [14]. There are four main broad learning theories in the education literature, namely Behaviorism, Cognitivism, Constructivism, and Connectiv-

Table 1. Number of visitors to libraries in ontario. (source: "public library statistics", ontario ministry of tourism, culture and sport, n.d. 05 Aug, 2015) [10].

\begin{tabular}{lcccc}
\hline & $\mathbf{2 0 1 0}$ & $\mathbf{2 0 1 1}$ & $\mathbf{2 0 1 2}$ & $\mathbf{2 0 1 3}$ \\
\hline Number of Active Cardholders & $5,133,356$ & $4,971,127$ & $4,913,281$ & $4,908,914$ \\
Library Visits Made in Person & $77,719,500$ & $75,058,800$ & $72,529,650$ & $71,928,150$ \\
\hline
\end{tabular}


ism. In Behaviorism knowledge is perceived as facts that can be transferred from teacher to student, however, learning is largely unknowable, that is, we can’t possibly understand what goes on inside a person. Cognitivism considers the learner as an information processor, opening up the black box of the mind; learning is managed in short term memory, and coded for long-term recall. Whereas Constructivism assumes that learners are not empty vessels to be filled with knowledge. It suggests that learners create knowledge as they try to make meaning of their experiences. Connectivism is considered to be the learning theory of the digital age, "a successor to behaviorism, cognitivism, and constructivism”. It is an integration of the principles explored by chaos, network, and complexity and self-organization theories. Principles of Connectivism (Siemens, 2004) [15] are:

- Learning and knowledge rest in diversity of opinions.

- Learning is a process of connecting specialized nodes or information sources.

- Learning may reside in non-human appliances.

- Capacity to know more is more critical than what is currently known.

- Nurturing and maintaining connections are needed to facilitate continual learning.

- Ability to see connections between fields, ideas, and concepts is a core skill.

- Currency (accurate, up-to-date knowledge) is the intent of all connectivist learning activities.

- Decision-making itself is a learning process. Choosing what to learn and the meaning of incoming information is seen through the lens of a shifting reality.

The principles emphasize on connections with information sources, different fields, and ideas. This connection can be made through social networks which are built on the premise of collaboration and sharing. They are ideal for connectivity particularly in external learning situations that are not always available, or feasible, in face-to-face classrooms (Mallon, 2013) [16]. It has been found that there is a strong positive effect of social capital on student satisfaction toward online learning and on virtual group learning outcomes (Lu et al., 2013) [17]. The concept of social capital is defined as an intangible asset produced by social relationships as a result of social networking (Coleman, 1994) [18]. It can also be defined as a feature of social organization including trust, norms, or networks that improve the efficiency of society by facilitating coordinated action and reducing transaction costs. There are two forms of social capital, namely bonding social capital, and bridging social capital. The former refers the thick confidence (particularized trust) between members of tight and highly-integrated groups while the latter implies the thin confidence (generalized trust) across primary belongings. It has been indicated that frequent library users have a higher social capital than those who use the library less often. Frequent library users are more apt to engage in civic life by voting, and are more trusting. As a result, social benefits gained from library use spill over into the community and add to the general quality of community life because the use of the library is a deliberate, if not always conscious, strategy to engage with fellow human beings (Johnson and Griffis, 2009) [19]. Learning experience is much more fruitful through conversation and interaction, on sharing, creation and participation as embedded in meaningful activities such as games or workflows (Downes, 2006) [20]. Furthermore, Hussain (2012) [21] studied the evolution of e-Learning riding of that of Web "point oh", and argued that a call for a new learning theory is not justified since most of the technologies that are to be a part of e-Learning are addressed by the principles of Connectivism. The same argument is applicable to Library3.0 if its principles can align with those of Connectivism.

\section{Library3.0}

School library is a private realm where dominating relational form is between students of the same school. Whereas, public library is a public realm, most of the visitors are strangers to each other, and the library's community activities constitute it as a parochial realm. Both types have to change their scope of services and tasks as a result of digitizing and digital swift. The evolution is not only technology driven due to that of Web and e-Learning "point oh", but also market driven as the core skills include creativity, interdisciplinary thinking, problem solving, and the ability to collaborate with others cannot be learned easily from books, but rather through learning-by-doing and social interaction in today's knowledge base economy. Not to mention most users work individually or within pre-organized groups who do not usually make new connections with co-present, unacquainted users (Bilandzic and Foth, 2013) [13], the attraction of traditional library learning arena is diminishing. Even with the adaption of Web3.0, electronic library can provides a new way for end users to collect online contents concerning comments, articles, Bolgs, photos, and videos in one place through parsing the linguistic expressions provided without the intentionally invoke specific application programs (Chu and Yang, 2012) [22], it cannot fully convert a traditional library into an information center, a meeting place, and a tech- 
nology hub. Library should embrace Web3.0 and go beyond. The facilities of library thus have to be changed as well as the role of librarian. It seems that the role of librarian has been weakened in the Library2.0 environment, they must be aware of the use of artificial intelligence management tools and semantic web in Library (Ahmed, 2015) [23]. The new role of librarian is collecting \& providing information and offering instruction in research techniques and information use rather than by physical presence as somewhere people go (Saw and Todd, 2007) [24]. They are not only the prominent apomediaries guiding library users on how best to locate, access and use credible information in myriad formats from diverse sources, at the point of need (Kwanya et al., 2013) [25], but also facilitators of connecting users. To convert a library into a personalizable, intelligent, sensitive and living institution with seamless engagement of library users, librarians and subject experts on a federated network of information pathways, Kwanya et al. (2013) [25], posited five principles of Library3.0, namely the library is intelligent, organized, federated networked, apomediated, and personalized. The meaning and attributes of each principle are listed in Table 2 below.

Table 2. Summary of library3.0/3.1 principles, attributes, and applied context-awareness (adapted from kwanya et al., 2013 [25]; noh, 2013 [26]; siemens, 2004 [15]; and hussain, 2012 [21]).

\begin{tabular}{|c|c|c|c|}
\hline Library3.0 principles & Attributes of Library3.0 & Applied context-awareness & $\begin{array}{l}\text { Principles of } \\
\text { Connectivism }\end{array}$ \\
\hline $\begin{array}{l}\text { The library is intelligent: } \\
\text { Self-renewing, flexible, } \\
\text { functional, integrated, } \\
\text { efficient, resilient, } \\
\text { autonomous and sensitive } \\
\text { (adaptive) }\end{array}$ & $\begin{array}{l}\text { Self-renewing, flexible, functional, } \\
\text { integrated, efficient, resilient, } \\
\text { autonomous and sensitive (adaptive) } \\
\text { via selective intelligence (wisdom of } \\
\text { the expert), ontology, smart (intuitive) } \\
\text { searching in natural language, } \\
\text { artificial intelligence }\end{array}$ & $\begin{array}{l}\text { Space on/off: } \\
\text { Controlling the space according to } \\
\text { user access. Turn off the light \& } \\
\text { other available technology once the } \\
\text { user entering the space. } \\
\text { Lobby: } \\
\text { Direct users to their desired space } \\
\text { using location based technology }\end{array}$ & $\begin{array}{l}\text { Learning may reside in } \\
\text { non-human appliances. }\end{array}$ \\
\hline $\begin{array}{l}\text { The library is organized: } \\
\text { Turn the unorganized web } \\
\text { of information into a } \\
\text { systematic and usable body } \\
\text { of knowledge by } \\
\text { exhaustively describing and } \\
\text { linking every piece of data } \\
\text { to enable ease of access }\end{array}$ & $\begin{array}{l}\text { Turning the unorganized web of } \\
\text { information into a systematic and } \\
\text { usable body of knowledge by } \\
\text { exhaustively describing and linking } \\
\text { every piece of data to enable ease of } \\
\text { access via semantic Web/Search }\end{array}$ & & $\begin{array}{l}\text { Ability to see } \\
\text { connections between } \\
\text { fields, ideas, and } \\
\text { concepts is a core skill. } \\
\text { Nurturing and } \\
\text { maintaining } \\
\text { connections is needed } \\
\text { to facilitate continual } \\
\text { learning }\end{array}$ \\
\hline $\begin{array}{l}\text { The library is a federated } \\
\text { network of information } \\
\text { pathways: Unifies disparate } \\
\text { information channels, } \\
\text { formats and environments } \\
\text { to ensure availability, } \\
\text { accessibility, search ability } \\
\text { and usability of credible } \\
\text { information }\end{array}$ & $\begin{array}{l}\text { Supports expressiveness and } \\
\text { interoperability to create synergies } \\
\text { between hitherto disparate } \\
\text { information resources and systems via } \\
\text { network of data (meaning), all-visible, } \\
\text { all-accessible Web, and Cloud } \\
\text { computing }\end{array}$ & & $\begin{array}{l}\text { Learning is a process of } \\
\text { connecting specialized } \\
\text { nodes or information } \\
\text { sources. Currency of } \\
\text { knowledge is important. }\end{array}$ \\
\hline $\begin{array}{l}\text { The library is apomediated: } \\
\text { Stand by the users and } \\
\text { guide them to high quality } \\
\text { information and services }\end{array}$ & $\begin{array}{l}\text { Stand by the users and guide them to } \\
\text { high quality information and services } \\
\text { without overbearing on the users via } \\
\text { social media, peers, \& librarians. }\end{array}$ & $\begin{array}{l}\text { Reference \& Safety services: } \\
\text { Riding on location based } \\
\text { technology, if the user spends over } \\
\text { certain duration at specific location } \\
\text { looking for specific subjects, } \\
\text { recommendations will be sent to } \\
\text { him/her accordingly. If the user } \\
\text { doesn't move over a certain time, } \\
\text { alert will be sent to library } \\
\text { personnel. }\end{array}$ & \\
\hline $\begin{array}{l}\text { The library is "my library": } \\
\text { Personalization similar to } \\
\text { what various service pro- } \\
\text { viders such as search en- } \\
\text { gines and the media were } \\
\text { offering their clients on } \\
\text { various Internet platforms }\end{array}$ & $\begin{array}{l}\text { Personalization of library services via } \\
\text { the design, management and delivery } \\
\text { of content based on known, observed } \\
\text { and predictive information. } \\
\text { The opportunity to interact with other } \\
\text { library users and to form or join } \\
\text { groups to enrich their learning } \\
\text { experience }\end{array}$ & $\begin{array}{l}\text { Access service: } \\
\text { The system detects the user identity } \\
\text { by reading the RFID card, \& then } \\
\text { pushes the recommendations } \\
\text { according to his/her borrowing } \\
\text { history. }\end{array}$ & $\begin{array}{l}\text { Learning and } \\
\text { knowledge rests in } \\
\text { diversity of opinions. } \\
\text { Capacity to know more } \\
\text { is more critical than } \\
\text { what is } \\
\text { currently known }\end{array}$ \\
\hline
\end{tabular}


To develop an intelligent system which can search and provide the services that users require in their current situation by analyzing and identifying the available contextual information such as the user's current location, time, people and devices in the vicinity, and the user's behavior and inputted data, Context-Awareness must be applied (Noh, 2013) [26]. He posited the use of context awareness as a core concept of the next generation digital libraries. Context is divided into "user context" and "environment context". The former represents the wide range of information described by the user and describing the user while the latter is the contextual information relating to the user's current user's current state, such as location or time zone, which cannot be described within the user's context (Hartmann, 2010) [27]. In short, Context-aware computing provides service to meet the needs of the users by recognizing certain situations, such as the user's location or environment. The author expounded the applications into five proposals: Applied context-awareness access service, Space on/off according to the user's access, Applied context-awareness lobby, Applied context-awareness reference service, and Applied context-awareness safety service. However, Noh (2013) [26] realized that Context-awareness has not been fully implemented in library yet, and thus the performance required further evaluation in following studies. The Principles of Library3.0, Context Awareness, and Connectivism are summarized in Table 2. It has been shown that the principles of Libray3.0, Context-Awareness, and Connectivism are aligned with each other.

Although the total number of library visitors has been declining in recent years as mentioned before, research has shown that the number of children borrowing books from libraries is at its highest in history. There are children zone where children can read, talk, and play on the floor. Studies have also shown that students prefer actual books to virtual books. Libraries remain to be the source of information, culture and wisdom (Gaiman, 2013) [28]. Another group of frequent library users are the elderly who may not be familiar with Web searching. They are healthy, retired, prefer to read newspaper and enjoy the air-con in the summer time but seldom make friends with other users. Regret that the elderly is committing more crimes than those aged 14 to 19 in recent Japan. This is because some elderly would be willing to commit crimes just to find companions and care in prison (The Economist, Victims' justice, 2015) [29]. Elderly loneliness is a common problem in this aging society. Library is a place which can mitigate this problem particularly for those who do not stay in elderly home by providing some group activities other than reading materials. For instance, just the like children zone, libraries can set up themed corners such as the smart senior room to group individuals with different interests and interactions; it creates companion opportunity for them. The smart senior room is equipped with rehabilitation computer programs in which seniors will be able to select music, digital instructor, 3D animation, so that participants can go through the program at their own pace. At the same time, interactive games involving the multi-touch display for multiple players; different activities, and events can be organized for interaction and fun. As such, in order to change libraries for books/medias in industrial society to libraries for man/human in networked/ knowledge society, it should provide different spaces/zones to cater the need for individual, quite space for reading, noisy space for group meeting, learning, meeting, discussion, and performance for mixed or different age groups, partnership with creative alliance to organize different types of function, and integrate with citizen services to attract users.

Schulz (2014) [30] realized the above societal demand. He posited a new model for the "Next" public library, providing "Experience, Discover, Participate, and Create” through digitization and individualization: Experience through inspiration space, Discover through learning space, Participate through meeting space, and Create through performance space. Inspiration space should open up to the irrational, emotional and chaotic by communicating a diversion of aesthetic experiences through storytelling or other artistic expressions within all kinds of media, cultural forms and genres. Learning space should provide experience and exploration of the world and thus strengthen their competences and possibilities through free and easy access to information and knowledge, music, play and many other activities. Meeting space is an open arena for meeting other people with different interests and values and encounter opinions that challenge you through discussions and debate in non-committal, random encounters through lounge décor with newspapers and café atmosphere as well as more organized meetings. Performance space can provide user interaction with others for inspiration and creation of new creative expressions in the encounter with art and culture through interactive games and writing-, sound- and video-workshops. Library services can then be tailored for personal needs and circumstances as well as giving users the opportunity to interact with other library users and to form or join groups to enrich their library experience (Storey, 2004) [31]. This echoed the findings of Aabø and Audunson (2012) [32] who explored how the libraries function as meeting places for across cultural, ethnic, generational, and social lines in a complex multicultural and digitized society. They found that a high proportion of the users constitute the library as a place related to 
work and education. Variety of users making the library stands out as a conglomerate of the community. Some people working alone use the library as their work space while some people in between jobs use it for jobsearching. Some people periodically use the public library as an inspiring place to work. It is an extension of the school, home or work place. Social capital can thus be built up and that the process of building social capital can be part of a community development process (Kilpatrick et al., 2003) [33]. In fact, all these aligned with the principle of "Personalization" in Library3.0 (Kwanya et al., 2013) [25]. Schulz (2014) [30] further illustrated the integration of citizen services such as issuing passport, driving license, and health security card with library can bring citizen in contact with library. Some cities like Oslo and Helsinki built concert hall and museum side by side with library so as to create a new icon in the city. In fact, a number of new public libraries all over the world had adapted the "Space" concept in one way or the others in their designs. To name a few: Vennesla Library in Norway is located in the city centre provides café, open meeting places, and a small scene, the building combines a library and house of culture. Black Diamond Library in Denmark includes a 600-seat auditorium, the Queen's Hall, used for concerts, literary events, theatrical performances and conferences. Surry Hills Library in Australia specializes in fashion and design titles, as well as having a significant lesbian, gay, bisexual and transgender collection. Nam June Paik Library in Korea aims to promote "non-linear and random access to information, and its production beyond the prescribed consumption." The user of information becomes the producer, and the static contents of the library turns dynamic through spontaneous expression and juxtaposition of ideas. The interior design of Biblioteca España Library in Colombia could "decontextualize the individual from the poverty that is experienced in the outside." The Maranello Library in Italy is intended to provide its visitors an introspective experience and visual connection with nature. The library of Muyinga in Burundi was built with the local know-how and traditions of Muyinga in mind. A "hallway porch" along a circulation space is often a part of the Burundian traditional housing as it provides a shelter from heavy rains and harsh sun.

\section{Library Development in Reality}

A full implementation of Library3.0 is still remote. In fact, there is no consensus on the actual definition of Library3.0. Build on the Library3.0 generation evolution graphical representation by Noh (2012) [34], this paper is trying to elaborate the technology available in the market for library in Figure 1, followed by a more detail explanations in Table 3.

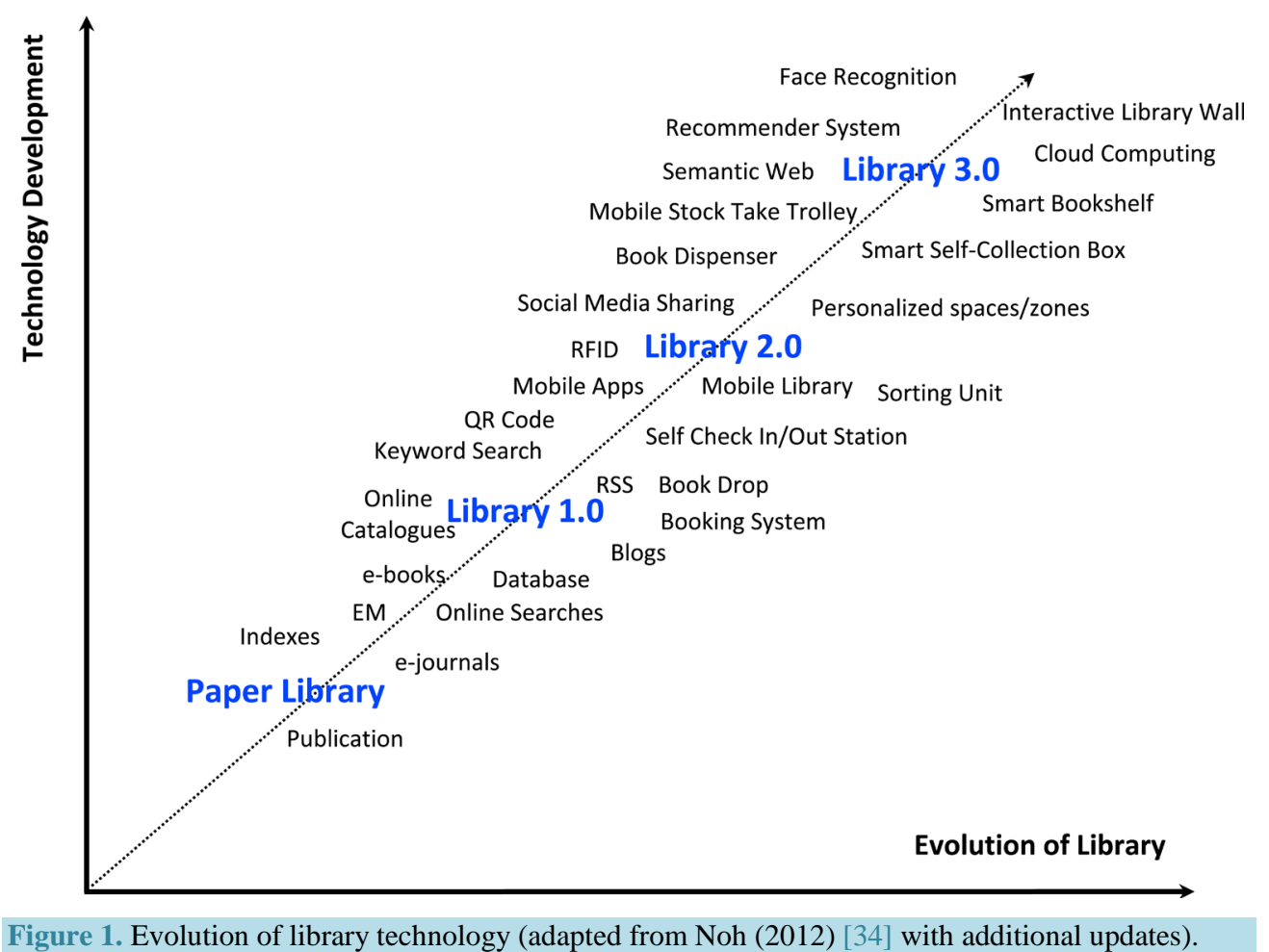


Table 3. Products for library3.0.

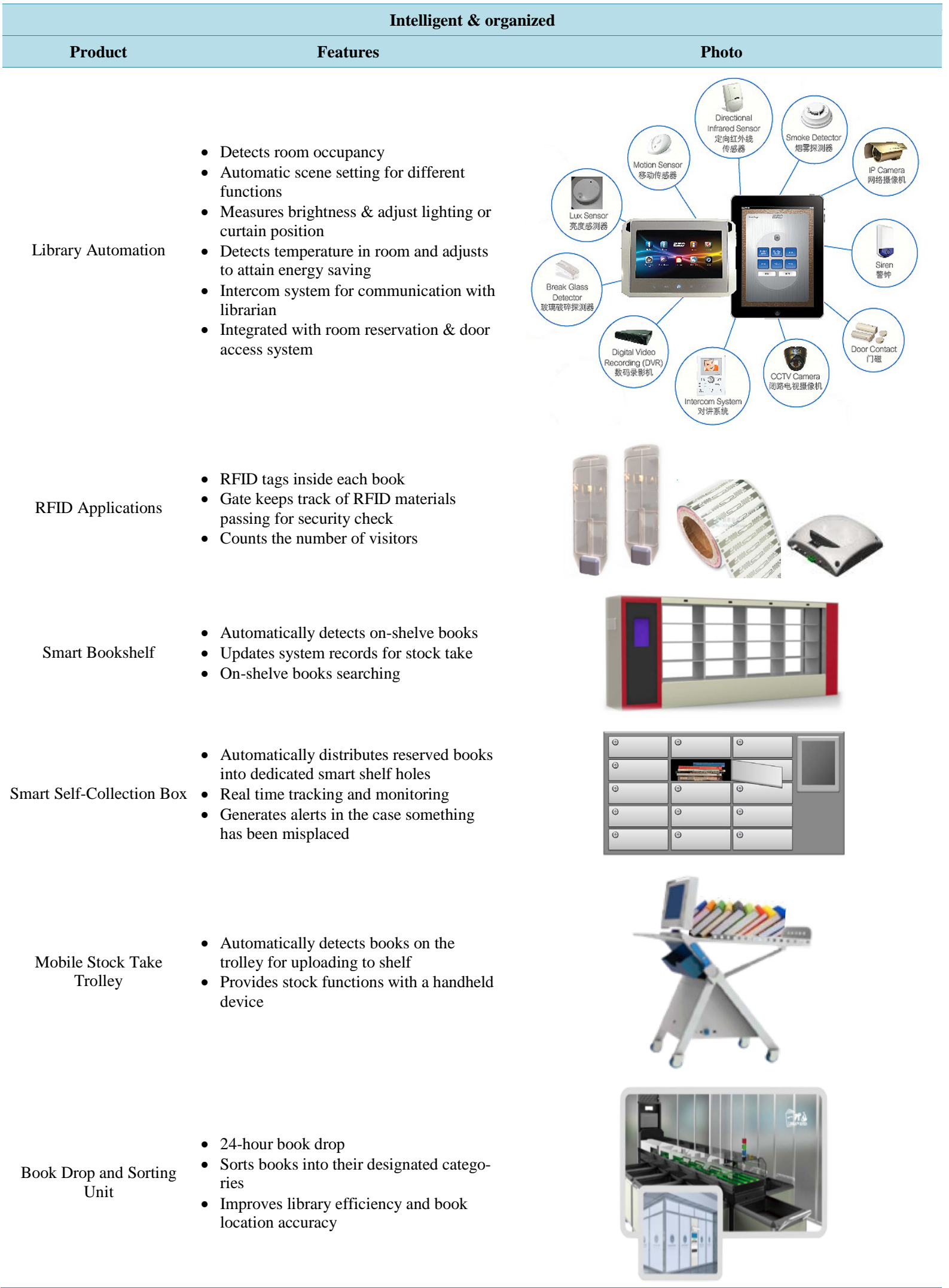




\section{Continued}

- On-line booking of library facilities such as function rooms and multimedia equipment

- Integrated with access control to authenticate users

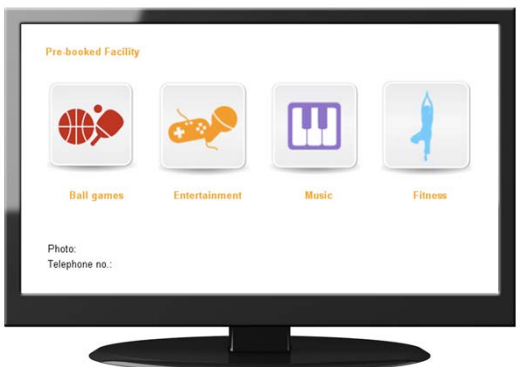

- Encourages self-service

- Hybrid system (HF/UHF/EM) to allow easy deployment and upgrades

Self Check In/Out Station

- Able to collect and analyzes user behavior

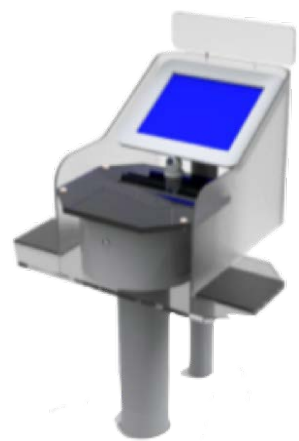

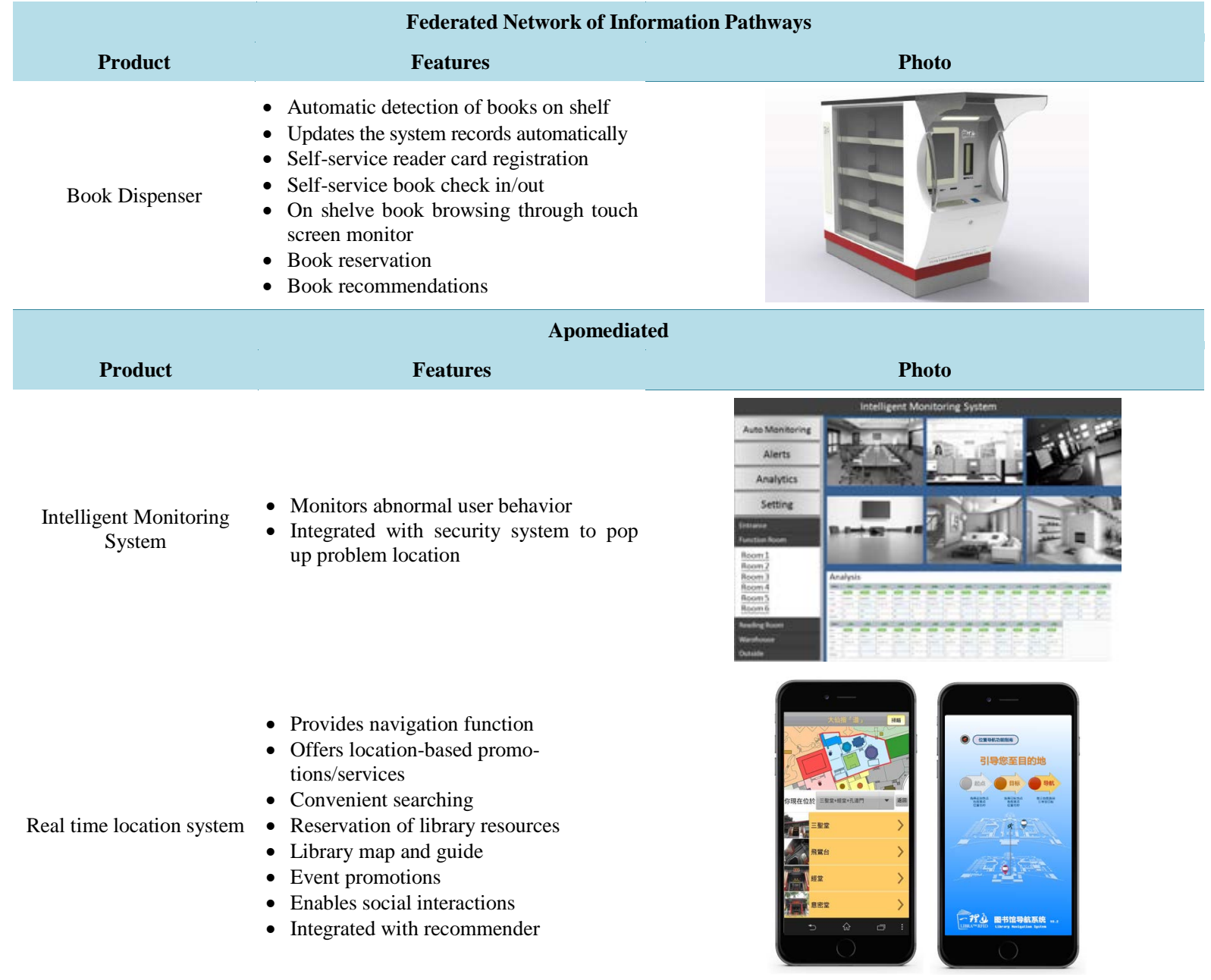




\begin{tabular}{|c|c|c|}
\hline \multicolumn{3}{|c|}{ “My Library” } \\
\hline Product & Features & Photo \\
\hline Recommender System & $\begin{array}{l}\text { - Recommends books based on user pre- } \\
\text { ferences } \\
\text { - Identifies user's previous records. Con- } \\
\text { tent-based or/and collaborative filtering }\end{array}$ & \\
\hline Face Recognition System & $\begin{array}{l}\text { - Identifies users for security or } \\
\text { recommender }\end{array}$ & \\
\hline Smart Senior Corner & $\begin{array}{l}\text { - Equipped with rehabilitation program } \\
\text { - Interactive games with multi-touch } \\
\text { display } \\
\text { - Equipped with physical and smart living } \\
\text { devices } \\
\text { - Video chats with overseas friends \& } \\
\text { relatives }\end{array}$ & \\
\hline Interactive Library Wall & $\begin{array}{l}\text { - Interactive participation platform } \\
\text { - Searching information in the Web } \\
\text { - Used for meetings and interactive } \\
\text { sharing }\end{array}$ & \\
\hline
\end{tabular}

\subsection{The Library Is Intelligent and Organized}

The attributes of "Intelligent" of the principle of Library3.0 are Self-renewing, flexible, functional, integrated, efficient, resilient, autonomous and sensitive (adaptive) via selective intelligence (wisdom of the expert), ontology, smart (intuitive) searching in natural language, and artificial intelligence while those of "Organized" are Turning the unorganized web of information into a systematic and usable body of knowledge by exhaustively describing and linking every piece of data to enable ease of access via semantic via Web/Search (Kwanya et al., 2013 [25]; Noh, 2013 [26]). The two principles are interrelated with each other in reality.

Web3.0 enables automatic clustering based on similarity and relationships in the document content for easy searching. Some libraries are using Resource Description Framework (RDF), Ontology, Resource Description and Access (RDA) to organize and describe their collections. In the hardware side, the development of internet of technology (IoT) has impacted library models and its operation. The IoT library consists of information object, independent network and intelligent application. Information object refers to library literature resources. Its items include hardware facilities and security access control. The independent network denotes network systems with self-management abilities that have exhibit self-configuration, self-healing, self-optimization and selfprotection capabilities. Libraries will offer learning experiences through self-serving and automation, efficient operation, user generated or personalized content, mobility and access 24/7. People of all ages will be able to experience and explore the world through convenient access to information and knowledge. Intelligent terminals help readers to use the library resources more efficiently, which therefore improves the resource utilization rates of libraries. It includes intelligent navigation retrieval terminal, security access control system, borrowing system and more (Wang and Zhao, 2015) [35].

To start-off with RFID enabled facility including tag inside each book, self-check in/out kiosks, security gate, and RFID enabled book-drop for return, the library becomes self-service. More advanced kiosk is equipped with a detector that allows the station to adjust its height according to the user's height. 
A 24-hour book drop along with a sorting unit improves the efficiency of the operation process. The device is able to efficiently and accurately sort the returned materials according to pre-defined categories. With the book drop and sorting unit, the workload of librarians is significantly reduced.

To make libraries even more efficient, smart bookshelves can be used. The smart bookshelf detects the on-shelf books automatically and updates the library management system database. The book list will then be generated on screen upon user enquiry at the input terminal at the side. The bookshelf also detects the book sequence, which allows for easy book searching. In addition, the mobile stock-take trolley can automatically detect the books on the trolley and informs the librarian of their positions on the shelf. The stock take trolley provides a book searching function and can identify what books are missing from the shelf after the stock-take with a handheld device. More advanced system such as Automated stored and retrieval system (ASRS) making use of robotic device is also available.

The booking system will then allow users to book library facilities such as function rooms and multimedia equipment. It will have customized ready scene settings and door access based on booking arrangements and more. Libraries can apply space on/of according to the user's access to enhance library automation functions. Within the function rooms, motion sensors will be installed to detect the flow of people in the area. Through identifying motion in the proximity, lights and air conditioners can be controlled automatically. When a user accesses the area, the lights and air conditioner will switch on. A light (lux) sensor will then adjust the brightness and temperature of the room accordingly depending on the traffic flow. The concept of "green energy" is not only practical but also educational to library users.

\subsection{The Library Is a Federated Network of Information Pathways}

The attributes of "Federated network of information pathways" of the principle of Library3.0 are supporting expressiveness and interoperability to create synergies between hitherto disparate information resources and systems via network of data (meaning), all-visible, all-accessible Web, and Cloud computing (Kwanya et al., 2013 [25]; Noh, 2013 [26]). Information-discovery system has been adopted by some universities to provide access to a large and diverse landscape of materials across different locations. It is flexible and scalable to support collaborative services, such as inter-library loan services and collaborative online reference in a union framework (Minami, 2008) [36]. Besides digital media, physical books in different locations can be delivered to users at their designated locations where the book dispenser is installed. One dispenser can store up around $200-400$ books. The upload and re-collection of books at the dispensers can be done during office hours while the users can borrow and return books after office hours. The reader (RFID/EM) at the input slot identifies the book and put it in an empty slot with a robotic arm. It retrieves the reserved book upon the user presentation of smart card. In addition, users are able to reserve books in library and ask for delivery to the dispenser at the built-in touch screen or mobile App. Due to the fact that users must use their library cards or smart cards to borrow books, the system will be able to identify their reading preferences and recommend books personalized for the users. Thus, providing applied context-awareness reference services to users.

\subsection{The Library Is Apomediated}

The attributes of "Federated network of information pathways" of the principle of Library3.0 are standing by the users and guide them to high quality information and services without overbearing on the users via social media, peers, \& librarians (Kwanya et al., 2013 [25]; Noh, 2013 [26]). Library3.0 glorifies disintermediation and self-service. With an Apps installed in the user portable devices and the Real Time Location System (RTSL) engine at the server or Cloud, his/her location inside the library can be monitored in real time, if the user spends over certain duration at specific location looking for specific subjects, recommendations will be sent to him/her accordingly. The user can then be guided to the appropriate location on a digital map shown on the smart device. Staff contacts and other relevant information can also be accessed at the mobile platform. More detail information about library resources, and reference services can be provided through QR codes on the catalogued items. In addition, to ensure the safety of the library and users, CCTVs will be used to monitor any anomaly such as unattended bags or unexpected behavior of users.

\subsection{The Library Is My Library}

The attributes of "My Library" of the principle of Library3.0 is personalization via the design, management and 
delivery of content based on known, observed and predictive information (Kwanya et al., 2013 [25]). The role of people evolved from passive consumers of information to that of active contributors because of some aspects of the Web2.0. Through the use of radio frequency identification (RFID) technology, which is a contactless identification technology, libraries will be able to identify users (Wang and Zhao, 2015) [35]. Besides RFID smart card, face recognition can also identify the user at the entrance. The recommender system can then recommend books personalized for each user based on the collected information. This generally involves the application of Machine Learning (ML) techniques, whose goal is learning to categorize new information items based on previously seen information (Lops et al., 2011) [37]. The two common techniques are content-based recommendation system and collaborative filtering. The former tries to recommend items similar to those a given user has liked in the past while the latter is based on the assumption that like minded people who have preferred on past items are likely to agree on future items. A hybrid system combining two methods is also available. Chatbots can even interact with users through intelligent conversation. The recommender system can then use the map presentation agent where the individual's learning locations are displayed on an electronic map guiding them the location of the books, and thus encourage readers to read more and enhance user experience (Chen, 2013) [38].

Library should provide opportunity to interact with other library users and to form or join groups to enrich their learning experience. It can offer mobile apps with group sharing functions, smart panels for meetings or discussions, and an intelligent function room for sharing to promote social interactions. Sharing and communication will be encouraged if different sessions designed for different age and interest groups can be provided. Library facilities rooms can facilitate group sharing or gathering activities, interest groups for activities like cooking, sports, gardening or music can be formed and sharing sessions can be organized. On the other hand, function rooms can be used to enjoy CDs or DVDs borrowed from the library. They can also be used for academic, business and sharing discussions. Online chat rooms can also be set up for library users to discuss books, movies, interests and more. In addition, different events such as story telling sessions, themed lectures, or themed book, CD recommendation sessions can be hosted. Interactive Multi-touch panels or wall are available for arousing user interests in searching and sharing information.

\section{Conclusion}

The adaption of Web3.0 provides convenience to library user on one hand but discourages library visit on the other. Library3.0 must embrace Web3.0 and go beyond. The role of public library has to be converted into an information center, a meeting place, and a technology hub through which social capital is built-up and spill over into the community adding to the general quality of community life. This study compares that the principles of Library3.0 (Kwanya et al., 2013) [25] and those of Connectivism (Siemens, 2004) [15]; literature review of the "Next" library, concludes that Library3.0 implementation can achieve this conversion with emphasis on "Personalization" in building communities for different age groups.

\section{Limitations and Future Research}

The proposal of this study is mainly based on literature review. It should be further verified by interview with library users particularly the elderly. Inclusion of citizen services and integration with other public utilities such as museum, opera, and exhibition hall with library is part the urban planning. This should be further explored at the municipal level.

\section{References}

[1] Hanekop, H. and Wittke, V. (2006) Das wissenschaftliche Journal und seine möglichen Alternativen: Veränderungen der Wissenschaftskommunikation durch das Internet. In: Hagenhoff, S. (Hrsg.), Internetökonomie in der Medienbranche, Universitätsverlag Göttingen.

[2] Kumar, S. and Grover, V.K. (2007) Electronic Journals: Impact on Scholarly Communication, User and Library. Library Herald, 45, 325-336.

[3] Montgomery, C.H. and Beilec, J.A. (2000) The Economic Impact of an Electronic Journal Collection on an Academic Library, Research and Advanced Technology for Digital Libraries. Springer, Berlin Heidelberg, 413-417.

[4] Folding Shelves (2013) The Economist. http://www.economist.com/news/international/21573966-e-books-mean-plot-twist-public-libraries-and-publishers-foldi ng-shelves 
[5] Best, D. (2006) Web 2.0: Next Big Thing or Next Big Internet Bubble? Technische Universiteit Eindhoven.

[6] Habib, M.C. (2006) Toward Academic Library 2.0: Development and Application of a Library 2.0 Methodology. Unpublished Master's Dissertation, University of North Carolina at Chapel Hill.

[7] Vacek, R. (2007) The Impact of Web 2.0 on Library Websites. Slideshare. http://www.slideshare.net/vacekrae/the-impact-of-web-20-on-library-websites

[8] Yang, X.Y., Wei, Q.Y. and Peng, X.D. (2009) System Architecture of Library 2.0. The Electronic Library, 27, $283-291$. http://dx.doi.org/10.1108/02640470910947629

[9] Belling, A., Rhodes, A., Smith, J., Thomson, S. and Thorn, B. (2011) Exploring Library 3.0 and beyond. http://www.libraries.vic.gov.au/downloads/20102011_Shared_Leadership_Program_Presentation_Day_/exploring_libr ary 3.pdf

[10] Public Library Statistics (2015) Ontario Ministry of Travel, Culture and Sports. http://www.mtc.gov.on.ca/en/libraries/statistics.shtml

[11] Morris, N. (2015) Number of Library Visitors Falls by 40 Million in Four Years as Austerity Measures Force Closures. The Independent.

http://www.independent.co.uk/news/uk/politics/number-of-library-visitors-falls-by-40-million-in-four-years-as-austerit y-measures-force-closures-10029860.html

[12] Murdoch, J.B. (2012) UK Library Stats: Falls in Numbers of Facilities, Visits and Books Issued. The Guardian. http://www.theguardian.com/news/datablog/2012/dec/11/library-visitors-books-issued-fall-performance-data

[13] Bilandzic, M. and Foth, M. (2013) Libraries as Coworking Spaces: Understanding User Motivations and Perceived Barriers to Social Learning. Library Hi Tech, 31, 254-273. http://dx.doi.org/10.1108/07378831311329040

[14] Smith, M.K. (2003) Learning Theory. Retrieved from The Encyclopedia of Informal Education. http://infed.org/mobi/learning-theory-models-product-and-process/

[15] Siemens, G. (2004) Connectivism: A Learning Theory for the Digital Age. International Journal of Instructional Technology \& Distance Learning, 2.

[16] Mallon, M.N. (2013) Extending the Learning Process: Using the Theory of Connectivism to Inspire Student Collaboration. Kansas Library Association College and University Libraries Section Proceedings, 3, 18-27. http://dx.doi.org/10.4148/culs.v1i0.1833

[17] Lu, J., Yang, J. and Yu, C.-S. (2013) Is Social Capital Effective for Online Learning? Information \& Management, 50, 507-522. http://dx.doi.org/10.1016/j.im.2013.07.009

[18] Coleman, J.S. (1994) Foundations of Social Theory. Harvard University Press, Cambridge, MA.

[19] Johnson, C.A. and Griffis, M.R. (2009) A Place Where Everybody Knows Your Name? Investigating Relationship between Public Libraries and Social Capital. Canadian Journal of Information and Library Science, 33, 159-191.

[20] Downes, S. (2006) Learning Networks and Connective Knowledge. Collective Intelligence and Elearning, 20, 1-26.

[21] Hussain, F. (2012) E-Learning 3.0 = E-Learning 2.0 + Web 3.0? International Conference on Cognition and Exploratory Learning in Digital Age (CELDA 2012), Madrid, 19-21 October 2012, $11-18$

[22] Chu, H.C. and Yang, S.W. (2012) Innovative Semantic Web Services for Next Generation Academic Electronic Library via Web 3.0 via Distributed Artificial Intelligence. In: Pan, J.-S., Chen, S.-M. and Nguyen, N.T., Eds., Intelligent Information and Database Systems, Springer, Berlin, 118-124. http://dx.doi.org/10.1007/978-3-642-28487-8_12

[23] Ahmed, W. (2015) Third Generation of the Web: Libraries, Librarians and Web 3.0. Library Hi Tech News, 32, 6-8. http://dx.doi.org/10.1108/LHTN-11-2014-0100

[24] Saw, G. and Todd, H. (2007) Library 3.0: Where Art Our Skills? World Library and Information Congress, 73rd IFLA General Conference and Council, Durban, 19-23 August 2007. http://archive.ifla.org/IV/ifla73/papers/151-Saw_Todd-en.pdf

[25] Kwanya, T., Stilwell, C. and Underwood, P.G. (2013) Intelligent Libraries and Apomediators: Distinguishing between Library 3.0 and Library 2.0. Journal of Librarianship and Information Science, 45, 187-197. http://dx.doi.org/10.1177/0961000611435256

[26] Noh, Y.H. (2013) A Study on Next-Generation Digital Library Using Context-Awareness Technology. Library Hi Tech, 31, 236-253. http://dx.doi.org/10.1108/07378831311329031

[27] Hartmann, M. (2010) Context-Aware Intelligent User Interfaces for Supporting System Use. Dissertation zur Erlangung des akademischen Grades. Dr.-Ing.

[28] Gaiman, N. (2013) Neil Gaiman: Why Our Future Depends on Libraries, Reading and Daydreaming. The Guardian. http://www.theguardian.com/books/2013/oct/15/neil-gaiman-future-libraries-reading-daydreaming

[29] Victims’ Justice (2015) The Economist. 
http://www.economist.com/news/asia/21660162-misplaced-panic-about-juvenile-crime-victims-justice

[30] Schulz, K. (2014) Library Transformation: Sketching the Future Library Transitioning to a Space for Citizens and Community Connections. https://plsmalmo.files.wordpress.com/2014/01/knud-schulz.pdf

[31] Storey, T. (2004) Libraries Look to Balance Technology, Cost and Usefulness. OCLC Newsletter. http://library.oclc.org/cdm/singleitem/collection/p267701coll28/id/148/rec/4

[32] Aabø, S. and Audunson, R. (2012) Use of Library Space and the Library as Place. Library \& Information Science Research, 34, 138-149. http://dx.doi.org/10.1016/j.lisr.2011.06.002

[33] Kilpatrick, S., Field, J. and Falk, I. (2003) Social Capital: An analytical Tool for Exploring Lifelong Learning and Community Development. British Educational Research Journal, 29, 417-432. http://dx.doi.org/10.1080/01411920301859

[34] Noh, Y.H. (2012) A Study on Library 3.0 Concept and Its Service Model. Journal of the Korean Society for Information Management, 27, 283-307. http://dx.doi.org/10.3743/KOSIM.2010.27.4.283

[35] Wang, T.J. and Zhao, P.J. (2015) Research and Application of Internet of Things in Intelligent Library. 1st International Conference on Information Sciences, Machinery, Materials and Energy, Chongqing, 11-13 April 2015, Atlantis Press, 684-687. http://dx.doi.org/10.2991/icismme-15.2015.141

[36] Minami, T. (2008) Library Services as Multi Agent System. In: Nguyen, N.T., Jo, G.S., Howlett, R.J. and Jain, L.C., Eds., Agent and Multi-Systems: Technologies and Applications, Springer, Berlin, 222-231. http://dx.doi.org/10.1007/978-3-540-78582-8 23

[37] Lops, P., de Gemmis, M. and Semeraro, G. (2011) Content-Based Recommender Systems: State of the Art and Trends. In: Ricci, F., Rokach, L., Shapira, B. and Kantor, P.B., Eds., Recommender Systems Handbook, Springer US, New York, 73-105. http://dx.doi.org/10.1007/978-0-387-85820-3_3

[38] Chen, C.M. (2013) An Intelligent Mobile Location-Aware Book Recommendation System That Enhances ProblemBased Learning in Libraries. Interactive Learning Environments, 21, 469-495. http://dx.doi.org/10.1080/10494820.2011.593525 